\title{
Investigation of cement based composites made with recycled rubber aggregate
}

\author{
Dragica Lj. Jevtić, Dimitrije M. Zakić, Aleksandar R. Savić \\ University of Belgrade, Faculty of Civil Engineering, Belgrade, Serbia
}

\begin{abstract}
The results of experimental investigations performed on cement based composites made with addition of recycled rubber as a partial replacement of natural river aggregate are presented in this paper. Different properties of cement based mortar were analyzed, both in fresh and in hardened state. The tested properties in the fresh state included density, consistency and volume of entrained air. In the hardened state, the following properties were tested: density, mechanical properties (compressive and flexural strength), modulus of elasticity, adhesion to concrete substrate, water absorption, freeze-thaw resistance and ultrasonic pulse velocity. The obtained results indicate that recycled rubber can be successfully applied as a partial replacement of natural river aggregate in cement based composites, in accordance with the sustainable development concept. The investigation showed that physical-mechanical properties of cementituous composites depend to a great extent on the percentage of replacement of natural river aggregate with recycled rubber, especially when the density, strength, adhesion and freeze-thaw resistance are concerned. The best results were obtained in the freeze-thaw resistance of such composites.
\end{abstract}

Keywords: composite, recycled rubber, mortar, natural river aggregate, cement, physical-mechanical properties.

Available online at the Journal website: http://www.ache.org.rs/HI/

\section{SCIENTIFIC PAPER}

UDC 666.9:691.555:628.4.04

Hem. Ind. 66 (4) 609-617 (2012)

doi: 10.2298/HEMIND111203010J
Cement based composites, concrete and mortar are the most applied construction materials today. The advantages of their use are reflected in various aspects, especially in the availability of component materials (binders, aggregates and water), but also in the simplicity of their preparation and favorable physical and mechanical properties in the hardened state.

Considering the actual concept of sustainable development, the growing global interest in using waste instead of traditional types of aggregates that could be applied in cement based composites is understandable. In order to encourage the application of cement based composites made with recycled aggregates, but also to deepen the understanding of their properties and establish a certain level of confidence in such aggregates, research of significant scale is performed all over the world. Regardless of the investigated type of aggregate, the question whether it should be used in cement based composites or not does not depend so much on the origin of the aggregate, but on the advantages/disadvantages it has on the composite material's physical and mechanical properties, as well as on durability. In all cases where such application is possible, the problem of materials recycling and their use as aggregates

Correspondence: D.Lj. Jevtić, Faculty of Civil Engineering, University of Belgrade, Bulevar kralja Aleksandra 73, 11000 Belgrade, Serbia.

E-mail: dragica@imk.grf.bg.ac.rs

Paper received: 3 December, 2011

Paper accepted: 1 February, 2012 should be approached with a positive attitude and with awareness that the alternative would be the disposal of waste material on landfills.

Regarding the application of the so-called "green" cement based composites, in some cases the recycled rubber can be used as a partial replacement of conventional aggregate - as it will be shown in this paper. Certain investigations on the possibility of using recycled rubber in asphalt concrete and ordinary concrete were conducted worldwide [1-3], but there is a lack of studies regarding the area of mortar composites.

Nowadays, the worldwide annual production of waste tires is estimated to approximately 1.4 billion units $[4,5]$. It is also estimated that tires represent one of the largest and most problematic sources of waste, because of their durability and huge production rate (more than four billion waste tires, generated over several decades, are being disposed of on landfills). According to the Directive EU 1999/31/EC, the disposal of waste tires on landfills is prohibited since 2003, while even the disposal of cut (shredded) tires is prohibited since 2009.

In Serbia, it is estimated that the quantity of waste tires, accumulated over the years, amounts to more than 50,000 tons. The annual production of waste tires in Serbia is estimated to 26,000 tons. According to the regulations on the procedures for waste tires management ("Sl. glasnik RS", No. 104/2009 and 81/2010), the disposal of waste tires on landfills is prohibited. These regulations set the annual rate of recycling of waste 
tires to $70 \%$, and their use for energy production purposes to $30 \%$ of the total quantity of waste tires collected in the previous year [4].

Having in mind the quantities of waste tires disposed on landfills, as well as their impact to environment, several solutions have been proposed to manage this problem. Whole waste tires are being usually used as infill for all kinds of embankments. The other, more effective way to utilize this waste material is controlled combustion, which led to huge application of waste tires as an alternative, or even primal industrial energy source. This way of utilization of waste tires is especially suitable for cement industry. Laboratory investigations showed that the products of combustion of waste tires differ little from the products of conventional fossil fuels combustion.

However, one of the most expensive but also most effective solutions for waste tire is reuse of recycled tire rubber. This application requires waste tires to be cut, shredded and granulated, so that the obtained aggregate could find its place in a wide range of applications: as material for drainage, infill for sandwich walls, sound barriers, road construction elements, sport facilities, concrete and mortar aggregate, etc.

In Serbia, the process of cutting, shredding and granulating waste tire rubber is done in several facilities (for instance, "Hemigum d.o.o." and "Eco Recycling"), which are based on mechanical grinding process [4].

\section{EXPERIMENTAL INVESTIGATION}

\section{Materials}

The following component materials were used for experimental investigation:

- Natural river aggregate "Moravac", Serbia, with the grain size between $0 / 4 \mathrm{~mm}$.

- Recycled rubber aggregate with the grain size
$<4 \mathrm{~mm}$, produced by "Tigar", Pirot, Serbia.

- Cement CEM II, PC 35M(V-L-S) $42.5 \mathrm{~N}$ produced by "Holcim", Novi Popovac, Serbia.

- Water from the city water-works.

The size distribution curve of natural river aggregate "Moravac" was obtained according to [6] and is shown in Figure 1.

Density of natural river aggregate and its bulk density in the loose state were determined according to [7] and amounted to 2617 and $1640 \mathrm{~kg} / \mathrm{m}^{3}$, respectively.

Size distribution curve of recycled rubber aggregate, obtained according to [6], is shown in Figure 2.

Density and bulk density of rubber aggregate in the loose state were determined according to [7] and amounted to 1150 and $470 \mathrm{~kg} / \mathrm{m}^{3}$, respectively.

Portland cement designated as CEM II, PC 35M (V-LS) $42.5 \mathrm{~N}$ produced by "Holcim", Novi Popovac, was used. Chemical composition of this type of cement is given in Table 1, and its physical and mechanical properties in Table 2.

\section{Mortar samples preparation}

In order to explore the possibility of partial replacement of natural river aggregate with recycled rubber, four test mixtures of cement based mortar were prepared. In all these mixtures, the quantities of cement and water were constant, while the replacement percentage of natural river aggregate with recycled rubber varied.

The physical and mechanical properties of composites made with recycled rubber aggregate were compared with the corresponding properties of the reference mortar (made without the rubber aggregate). The investigated fresh mortar properties included: density, consistency and percentage of entrained air, whereas hardened mortar properties investigations included: density, strength, water absorption, freeze-

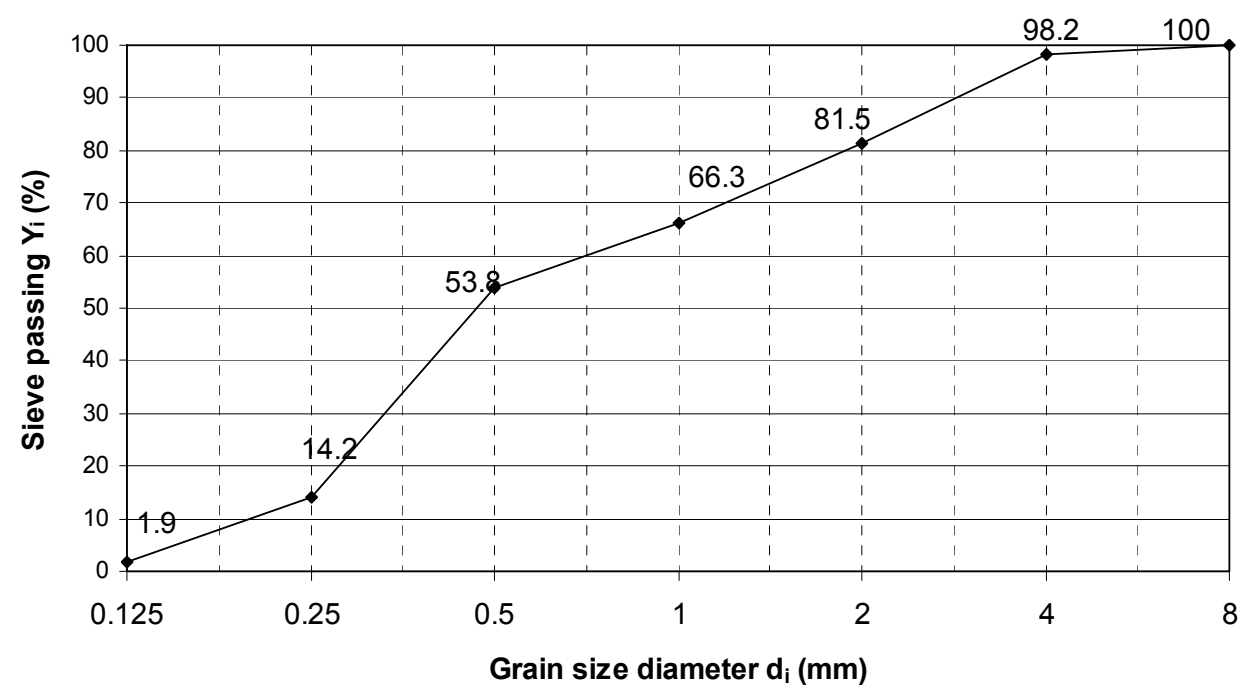

Figure 1. Grain size distribution curve of natural river aggregate. 


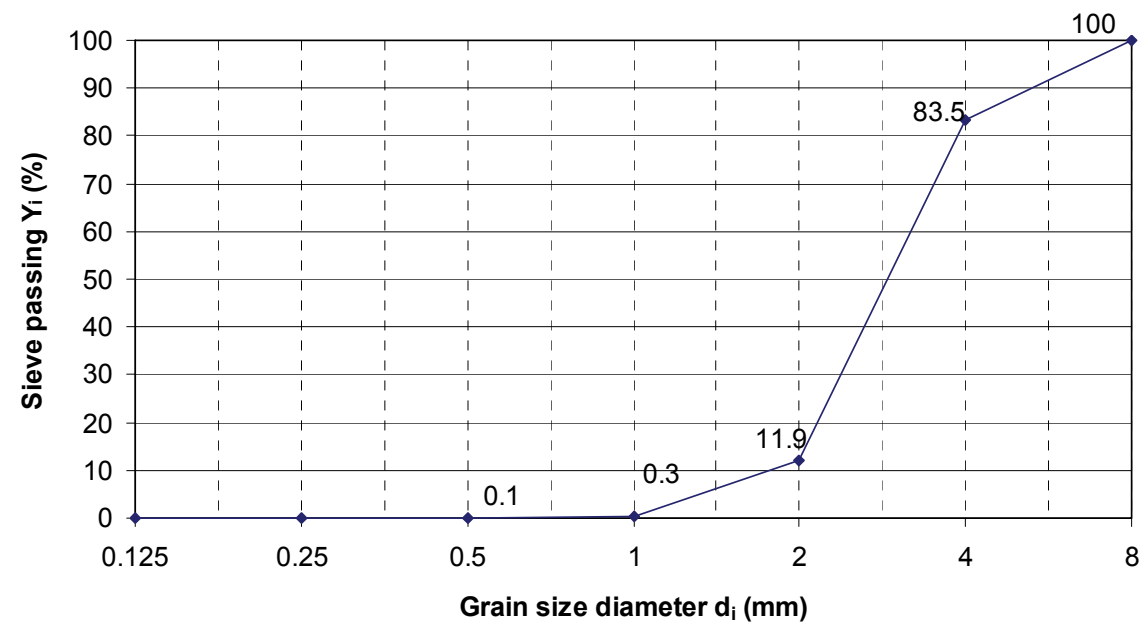

Figure 2. Grain size distribution curve of the used rubber aggregate.

thaw resistance, adhesion, modulus of elasticity and ultrasonic pulse velocity.

Table 1. Chemical composition of cement

\begin{tabular}{lc}
\hline Component & Content, mass\% \\
\hline $\mathrm{SiO}_{2}$ & 21.44 \\
$\mathrm{Al}_{2} \mathrm{O}_{3}$ & 7.56 \\
$\mathrm{Fe}_{2} \mathrm{O}_{3}$ & 2.93 \\
$\mathrm{CaO}$ & 56.68 \\
$\mathrm{MgO}$ & 1.78 \\
$\mathrm{SO}_{3}$ & 1.75 \\
$\mathrm{~S}^{2-}$ & 0.05 \\
$\mathrm{Na}_{2} \mathrm{O}$ & 0.40 \\
$\mathrm{~K}_{2} \mathrm{O}$ & 0.54 \\
$\mathrm{MnO}$ & 0.227 \\
Ignition loss & 6.66 \\
\hline
\end{tabular}

Table 1. Continued

\begin{tabular}{lc}
\hline Component & Content, mass\% \\
\hline Insoluble residue in $\mathrm{HCl} / \mathrm{Na}_{2} \mathrm{CO}_{3}$ & 5.81 \\
Insoluble residue in $\mathrm{HCl} / \mathrm{KOH}$ & 2.69 \\
$\mathrm{CO}_{2}$ & 5.07 \\
$\mathrm{Cl}^{-}$ & 0.007 \\
Free $\mathrm{CaO}$ & 0.71 \\
\hline
\end{tabular}

Apart from the reference mortar (marked as "E"), three more series of cement based composites were prepared. These series (marked as "G1","G2" and "G3"), were made with 10, 20 and 30\% (by volume) of recycled rubber aggregate.

All series of mortar were made using following proportions: aggregate:cement $=3: 1$ (by mass) and water/

Table 2. Standard physical and mechanical properties of cement

\begin{tabular}{|c|c|c|}
\hline \multicolumn{3}{|c|}{ Physical properties } \\
\hline \multirow[t]{8}{*}{ Powder } & \multicolumn{2}{|l|}{ Fineness } \\
\hline & Sieve residue $0.09 \mathrm{~mm}, \%$ & 0.0 \\
\hline & \multicolumn{2}{|l|}{ Specific surface (Blaine), $\mathrm{cm}^{2} / \mathrm{g}$} \\
\hline & & 4470 \\
\hline & Density, $\mathrm{kg} / \mathrm{m}^{3}$ & 2960 \\
\hline & \multicolumn{2}{|c|}{ Bulk density, $\mathrm{kg} / \mathrm{m}^{3}$} \\
\hline & Loose state & 890 \\
\hline & Compacted state & 1440 \\
\hline \multirow[t]{7}{*}{ Paste } & Water for standard consistency, \% & 29.6 \\
\hline & \multicolumn{2}{|l|}{ Setting time, $\min$} \\
\hline & Initial & 225 \\
\hline & Final & 275 \\
\hline & \multicolumn{2}{|l|}{ Soundness } \\
\hline & Cake & Sound \\
\hline & Le-Chatelier, mm & 1.0 \\
\hline
\end{tabular}


/cement ratio $=0.50$. The exact quantities of component materials for all mortar series are shown in Table 3.

The mixing of cement based composites was performed using the laboratory mixer RILEM-CEM, in the following steps: first, water and cement were mixed for $30 \mathrm{~s}$, then, the rubber aggregate was added in another $30 \mathrm{~s}$ (for series G1, G2 and G3), and finally, the natural river aggregate was added to the mixture. The total duration of mixing process was $120 \mathrm{~s}$ for all mixtures. Fresh composites obtained this way were placed in molds and then compacted using standard vibrating table.

After compaction, samples were cured [8].

\section{Properties of composites}

The following properties of composites were investigated in the fresh state:

- Density [9].

- Consistency (flow table method) [10].

- Percentage of entrained air [11].

The following properties were investigated on hardened cement based composites:

- Density [12].

- Mechanical properties (flexural and compressive strength) [8].

- Modulus of elasticity [13].

- Adhesion (pull-off method) [14].

- Water absorption [15].

- Ultrasonic pulse velocity [16].

- Freeze-thaw resistance [17].

For adhesion testing, a substrate layer in the form of finished (precast) concrete slabs measuring $40 \mathrm{~cm} \times$ $\times 40 \mathrm{~cm} \times 5 \mathrm{~cm}$ was chosen. After preparing, fresh mortar mixtures were applied manually to the surface of the slabs, in a layer of $3 \mathrm{~cm}$. Concrete slabs were precleaned using a steel brush and soaked with water one hour before applying the mortar. The curing of the mortar layer was done over the next 28 days using a wet cloth. The adhesion was tested using a "Pull-off" tester produced by Controls, with the tension force increment of $0.5 \pm 0.1 \mathrm{kN} / \mathrm{s}$.

Determination of modulus of elasticity of investigated composites was carried out at the age of 28 days on prismatic specimens $(4 \mathrm{~cm} \times 4 \mathrm{~cm} \times 16 \mathrm{~cm})$. During this test, the initial stress was $0.5 \mathrm{MPa}$, while the highest stress value was adopted to be $\mathrm{fp} / 3$ (a value that is three times lower than the compressive strength of mortar). The value of the modulus of elasticity, $E$, was calculated on the basis of strain difference measured during the last cycle of loading.

Water absorption measurement was carried out on prismatic specimens $(4 \mathrm{~cm} \times 4 \mathrm{~cm} \times 16 \mathrm{~cm})$. After the curing period ( 28 days in water), all specimens were dried to constant weight at a temperature of 100-110 ${ }^{\circ} \mathrm{C}$ and then the saturation was carried out using the gradual immersion method.

Ultrasonic pulse velocity measurement results were obtained using PUNDIT apparatus, which measured the time (in $\mu \mathrm{s}$ ) required for the ultrasonic waves to travel between the probes - the transmitter and receiver, through prismatic $(4 \mathrm{~cm} \times 4 \mathrm{~cm} \times 16 \mathrm{~cm})$ specimens.

Testing of freeze-thaw resistance was carried out on composite specimens older than 28 days, after complete saturation with water. Freeze-thaw cycles were applied on the specimens using the climatic chamber, providing that the specimens were kept at temperature $-20{ }^{\circ} \mathrm{C}$ for $4 \mathrm{~h}$ and then in water (at room temperature), also for a period of $4 \mathrm{~h}$. After 25 cycles, the mass loss and compressive strength decrease were determined, in comparison to specimens that were not exposed to freeze-thaw cycles.

\section{RESULTS}

The obtained results of investigated properties of composites in the fresh state are shown in the Table 4.

Table 4. Basic properties of fresh composites

\begin{tabular}{lcccc}
\hline Mortar type & Reference (E) & G1 & G2 & G3 \\
\hline Consistency - flow, mm & 156 & 165 & 177 & 180 \\
Air entrainment, $\Delta p / \%$ & 4.25 & 4.50 & 4.75 & 5.25 \\
Fresh mortar density, & 2290 & 2262 & 2182 & 2108 \\
$\gamma_{\mathrm{m}, \mathrm{sv}} / \mathrm{kg} \mathrm{m}^{-3}$ & & & & \\
\hline
\end{tabular}

As far as the properties of composites in the hardened state are concerned, the density change was monitored at the age of $3,7,14$ and 28 days. The results of these tests are shown in Figure 3.

Furthermore, mechanical properties - flexural and compressive strength were tested at the age of 3, 7 and 28 days, and the results of these tests are shown in the graphs (Figures 4 and 5). The appearance of the specimens after failure is shown in Figure 6.

The adhesion to the concrete substrate was calculated as the terminal value of tension stress (terminal

Table 3. Quantities of component materials for mortar mixes

\begin{tabular}{lcccc}
\hline Component & Water, $m_{\mathrm{v}} / \mathrm{g}$ & Cement, $m_{\mathrm{c}} / \mathrm{g}$ & Rubber, $m_{\mathrm{g}} / \mathrm{g}$ & Sand, $m_{\mathrm{p}} / \mathrm{g}$ \\
\hline Reference $-\mathrm{E}$ & 225 & 450 & - & 1350 \\
10 vol.\% of rubber $-\mathrm{G} 1$ & 225 & 450 & 35.2 & 1227 \\
20 vol.\% of rubber $-\mathrm{G} 2$ & 225 & 450 & 64.5 & 1125 \\
30 vol.\% of rubber $-\mathrm{G} 3$ & 225 & 450 & 89.3 & 1038 \\
\hline
\end{tabular}




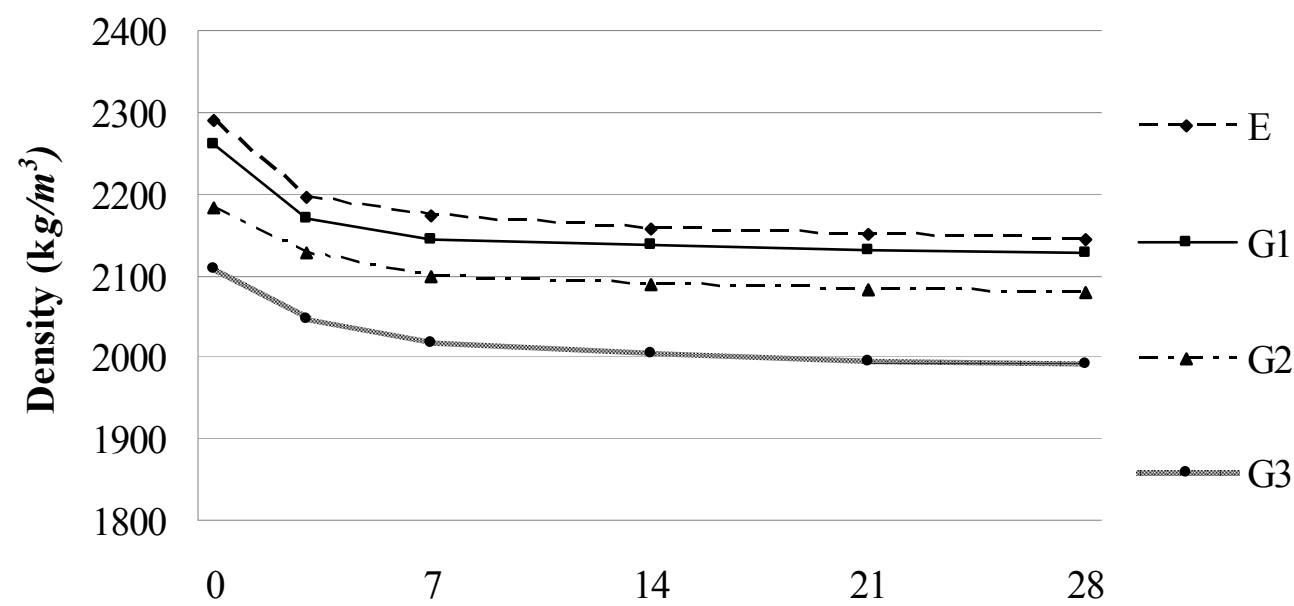

Age (days)

Figure 3. The change of composites' density over time.

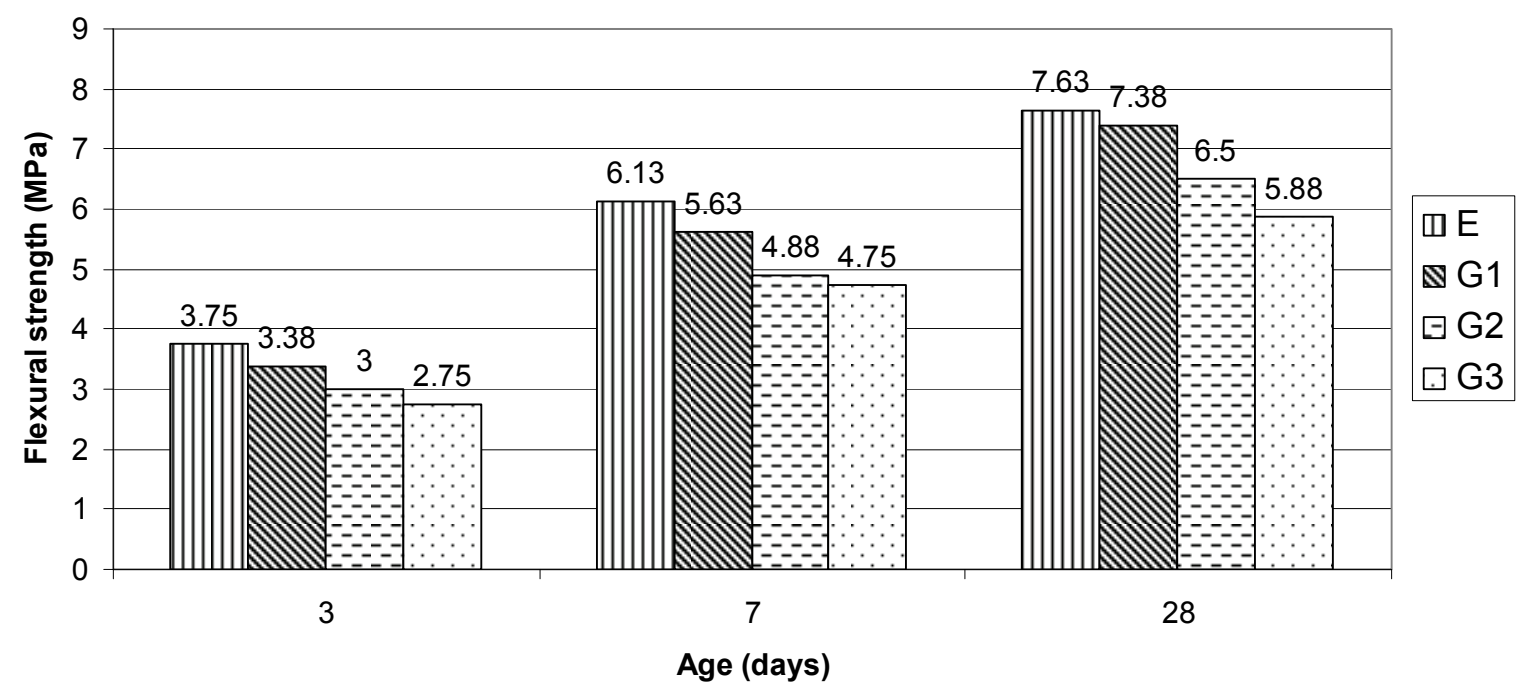

Figure 4. Composites' flexural strength increase in time.

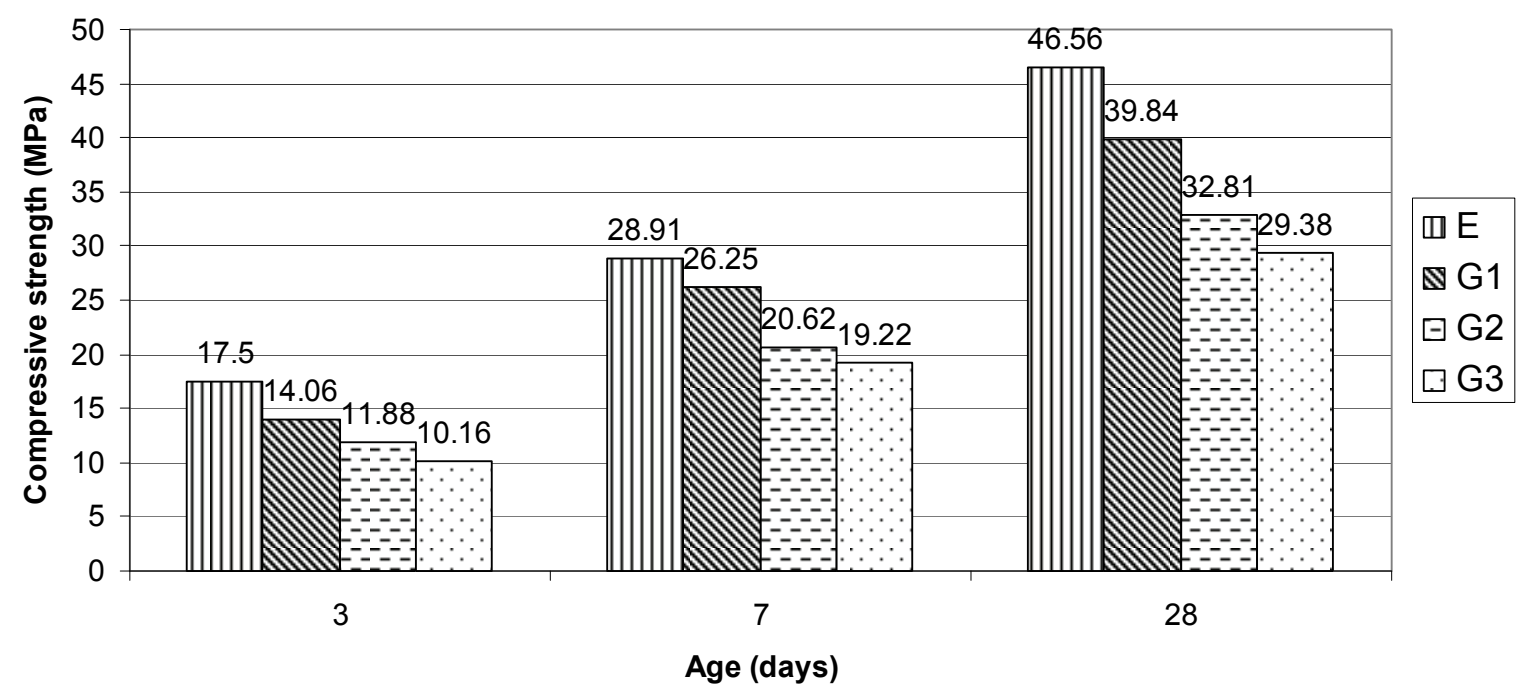

Figure 5. Composites' compressive strength increase in time. 


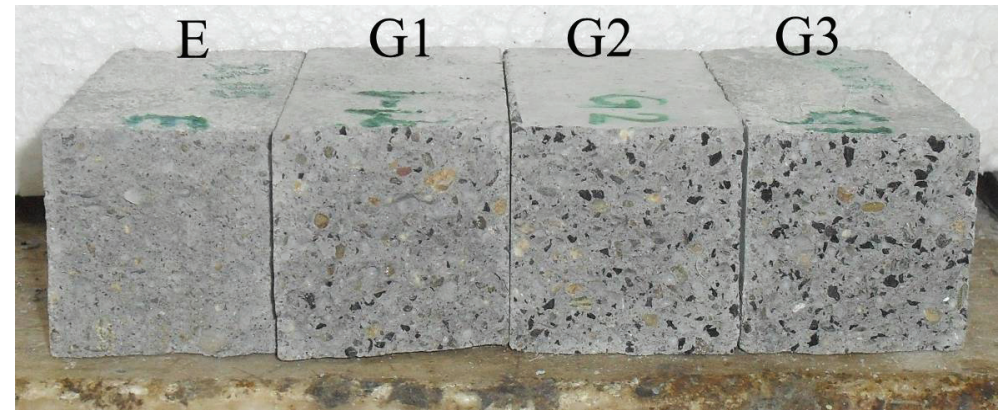

Figure 6. Appearance of mortar specimens after failure.

value of the force divided by cross section area of the cylinder). The results of this test are shown in Figure 7.

Water absorption test results for investigated cement based composites are shown in Table 5 .

The complete results of all the tests concerning physical-mechanical properties of investigated composite materials are also given in Table 5.

\section{DISCUSSION}

The obtained results show that the partial replacement of natural river aggregate with recycled rubber aggregate in series $\mathrm{G} 1, \mathrm{G} 2$ and $\mathrm{G} 3$ (10, 20 and 30 vol.\%) causes the density reduction of mortar in the fresh state, ranging between 1.2 and $7.9 \%$. These results are consistent with previous studies [20]. Obviously, the reduction in density depends on the percentage of replacement of natural river aggregate with recycled rubber aggregate.

As it has been reported earlier [21-23], for this type of materials the consistency of cement based composites changes in the presence of recycled rubber aggregate; in this case, there was an increase in consistency for all the mixtures, depending on the replacement per-

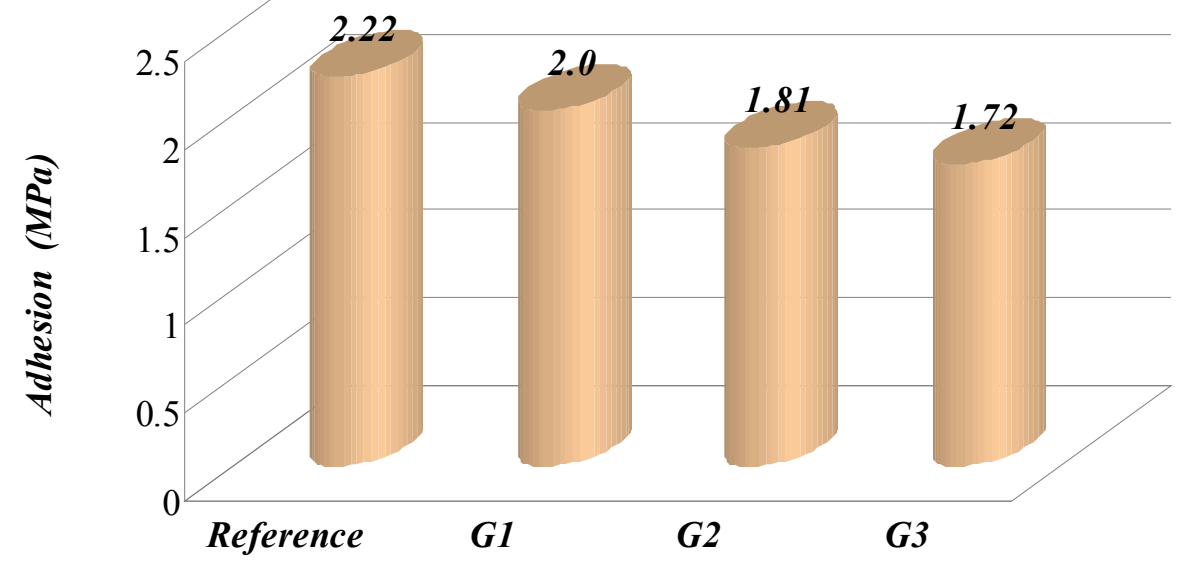

Figure 7. Adhesion of composites to concrete slab.

Table 5. Basic physical and mechanical properties of hardened mortar

\begin{tabular}{lcccc}
\hline \multirow{2}{*}{ Parameter } & \multicolumn{3}{c}{ Series } \\
\cline { 2 - 5 } & $\mathrm{E}$ & $\mathrm{G} 1$ & $\mathrm{G} 2$ & $\mathrm{G} 3$ \\
\hline Hardened mortar density, $\gamma_{\mathrm{m}} / \mathrm{kg} \mathrm{m}^{-3}$ & 2143 & 2127 & 2079 & 1990 \\
Flexural strength-28d, MPa & 7.63 & 7.38 & 6.5 & 5.88 \\
Compressive strength-28d, MPa & 46.56 & 39.84 & 32.81 & 29.38 \\
Modulus of elasticity E, GPa & 25.6 & 23.0 & 22.4 & 21.6 \\
Adhesion, MPa & 2.22 & 2.00 & 1.81 & 1.72 \\
Water absorption, \% & 7.64 & 8.15 & 8.82 & 9.30 \\
Ultrasonic pulse velocity, m/s & 4082 & 3604 & 3445 & 3239 \\
Strength retain after freeze-thaw cycles, \% & 25.1 & 28.8 & 33.9 & 42.1 \\
Mass loss under freeze-thaw cycles, \% & 10.48 & 5.29 & 0.18 & 0.15 \\
\hline
\end{tabular}


centage of natural river aggregates with recycled rubber. Thus, the consistency (flow) of the reference mixture (E) was $156 \mathrm{~mm}$, and for the mixtures $\mathrm{G} 1, \mathrm{G} 2$ and $\mathrm{G} 3$, it amounted to 165,177 and $180 \mathrm{~mm}$, respectively.

As far as the hardened mortar is concerned, a change has also been recorded, mainly through reduction of density in hardened state, but also through changes in mechanical properties.

The increase of partial replacement of natural river aggregate affects the decrease of mechanical properties, especially flexural and compressive strength. The replacement of 10,20 and 30 vol.\% of natural river aggregate caused the reduction in flexural strength of $3.2,14.8$ and $16.4 \%$, respectively, and the reduction in compressive strength (after 28 days) was 14.4, 29.5 and 36.9\% (Table 5).

The addition of recycled rubber aggregate caused a decrease of the modulus of elasticity. This decrease amounted to $10.2,12.5$ and $15.6 \%$ for the composite series $\mathrm{G1}, \mathrm{G} 2$ and $\mathrm{G} 3$, respectively.

Concerning the adhesion of cement based composites to a concrete substrate, the obtained results showed a decline compared to the reference mortar of 8.6, 18.5 and $22.5 \%$ for composites G1, G2 and G3, respectively. These test results comply with results published elsewhere [2,20,22].

The addition of recycled rubber aggregate also affects the increase in porosity of cement based composites $[3,24,25]$; this was investigated by analyzing the change of ultrasonic pulse velocity through composite material. This property showed a decrease from the reference mortar in the amount of $11.7,16.8$ and $20.6 \%$, for series G1, G2 and G3, respectively. Consequently, there was an increase in water absorption of 6.7, 15.4 and $21.7 \%$ for series $G 1, G 2$ and G3, compared to the reference composite, respectively.

The freeze-thaw resistance test showed increased resistance of rubberized mortar, which is also consistent with previous studies [26]. The increment varied with the percentage of used rubber aggregate, amounting to $3.4,8.8$ and $17.0 \%$ for series G1, G2 and G3, in comparison to the reference mortar.

\section{CONCLUSIONS}

After the performed investigation, the following conclusions may be derived:

- Partial replacement of natural river aggregate with recycled rubber aggregate (in amounts of 10,20 and 30 vol.\%) has significant impact on properties of fresh and hardened cement based composites. In the fresh mortar, increase of incorporated recycled rubber aggregate contributes to the reduction in density and the increase in consistency (fluidity) of the composite, as well as to the percentage of entrained air in the fresh mixture, to some extent.
- The use of recycled rubber aggregate increases the porosity of composite, which was concluded after monitoring the ultrasonic pulse velocity through material.

- Mechanical properties, such as flexural and compressive strength, adhesion to concrete substrate and modulus of elasticity, tend to decrease with the increased addition of recycled rubber aggregate. However, it should be noted that the compressive strength after 28 days for the $\mathrm{G} 3$ mortar series reached the value of approximately $30 \mathrm{MPa}$, while the adhesion exceeded 1.5 MPa, which are considered as the minimum values for repair mortar composites.

- The freeze-thaw resistance, expressed either through the mass loss or the loss of compressive strength of mortar, increased with the addition of recycled rubber aggregate.

- The mortar made with $10 \%$ of natural river aggregate replacement showed the optimal properties, in terms of physical, mechanical and economic parameters.

All the above stated conclusions indicate that the recycled rubber aggregate can be successfully applied in lightweight cement based composites (such as insulating, soundproofing or repair mortars). However, the potential user should be aware of the fact that the percentage of replacement of natural river aggregate with recycled rubber aggregate significantly affects the properties of cement based composites and their possible application.

The durability of the investigated rubberized mortar has been improved compared to the reference mortar, which encourages the further research of this type of cement based composites.

\section{Acknowledgement}

The work reported in this paper is a part of the investigation within the research project TR 36017 "Utilization of by-products and recycled waste materials in concrete composites in the scope of sustainable construction development in Serbia: investigation and environmental assessment of possible applications", supported by the Ministry of Education, Science and Technological Development of the Republic of Serbia. This support is gratefully acknowledged.

\section{REFERENCES}

[1] R. Siddique, Waste Materials and By-Products in Concrete, Scrap Tires, Chapter 4, Springer; $1^{\text {st }}$ ed., 2007, pp. 121-145.

[2] I.B. Topcu, The properties of rubberized concrete, Cement Concrete Res. 25 (1995) 304-310.

[3] D. Fedroff, S. Ahmad, B.Z. Savas, Mechanical properties of concrete with ground waste tire rubber, Report No. 
1532, Transportation Research Board, Washington, DC, 1996, pp. 66-72.

[4] D.D. Stanojević, M.B. Rajović, D.V. Rajković, Management of used tires, accomplishments in the world, and situation in Serbia, Hem. Ind. 65 (2011) 627-738 (in Serbian).

[5] P.S. Đekić, G.M. Radenković, The influence of the share of recycled tire on the rubber mixture properties, Hem. Ind. 64 (2010) 247-252 (in Serbian).

[6] SRPS EN 933-1:2009, Tests for geometrical properties of aggregates - Part 1: Determination of particle size distribution - Sieving method.

[7] SRPS B.B8.031:1982, Crushed aggregate - Determination of particle density and water absorption.

[8] SRPS EN 196-1, Methods of testing cement - Part 1: Determination of strength.

[9] SRPS EN 1015-6:2008, Methods of test for mortar for masonry - Part 6: Determination of bulk density of fresh mortar.

[10] ASTM C230 / C230M - 08, Standard Specification for Flow Table for Use in Tests of Hydraulic Cemen.

[11] SRPS B.C8.050:1981, Air content of hydraulic cement mortar.

[12] SRPS EN 1015-10:2008, Methods of test for mortar for masonry - Part 10: Determination of dry bulk density of hardened mortar.

[13] SRPS ISO 6784:2000, Concrete - Determination of static modulus of elasticity in compression.

[14] SRPS EN 1542:2010, Products and systems for the protection and repair of concrete structures - Test methods - Measurement of bond strength by pull-off.

[15] SRPS B.B8.010:1981, Testing of natural stone. Water absorption determination.

[16] SRPS U.M1.042:1998, Concrete, hardened - Determination of ultrasonic pulse velocity.

[17] SRPS U.M1.016:1993, Concrete - Method of test for resistance of concrete against freezing and thawing.
[18] J.C. Pais, P.A.A. Pereira, The improvement of pavement performance using asphalt rubber hot mixes, International Symposium on Highway and Bridge Engineering, Romania, 2007.

[19] M.C. Zantetti, G. Genon, Recycle of used tyres: Cryogenic disintegration and reuse of the obtained products, Sustainable Waste Management and Recycling: Challenges and Opportunities. Vol. 3, Used/Post-Consumer Tyres, 2004, pp. 119-126.

[20] C. Albano, N. Camacho, J. Reyes, J.L. Feliu, M. Hernandez, Influence of scrap rubber addition to portland concrete composites, destructive and non-destructive testing, Compos. Struct. 71 (2005) 439-446.

[21] D. Raghvan, H. Huynh, C.F. Ferraris, Workability, mechanical properties and chemical stability of a recycled tire rubber-filled cementitious composite, J. Mat. Sci. 33 (1998) 1745-1752.

[22] D. Jevtić, D. Zakić, A. Savić, Application of recycled materials for production of sustainable cementitious composites, Plenary and Invitation Paper, Proceedings of $11^{\text {th }}$ International Conference RaDMI, Research and Development in Mechanical Industry, RaDMI 2011 Soko Banja, Serbia, 2011, pp. 110-121.

[23] D. Jevtić, D. Zakić, A. Savić, A. Radević, Properties of composite materials made with the addition of recycled rubber, Proceedings of Abstracts IConSSM 2011, The 3rd International Congress of Serbian Society of Mechanics, Vlasina Lake, Serbia, 2011, p. 133.

[24] N.N. Eldin, A.B. Senouci, Rubber-tire particles as concrete aggregates, ASCE J. Mat. Civil Eng. 5 (1993) 478$-496$.

[25] Z.K. Khatib, F.M. Bayomy, Rubberized portland cement concrete, ASCE J. Mat. Civil Eng. 11 (1999) 206-213.

[26] K.A. Paine, R.K. Dhir, R. Moroney, K. Kopasakis, Use of crumb rubber to achieve freeze thaw resisting concrete, Proceedings of the International Conference on Concrete for Extreme Conditions, University of Dundee, Scotland, 2002, pp. 486-498. 


\section{IZVOD}

\section{ISTRAŽIVANJE KOMPOZITA NA BAZI CEMENTA SPRAVUENIH SA RECIKLIRANOM GUMOM KAO AGREGATOM}

Dragica Lj. Jevtić, Dimitrije M. Zakić, Aleksandar R. Savić

Univerzitet u Beogradu, Građevinski fakultet, Beograd, Srbija

(Naučni rad)

U radu su prikazani rezultati sopstvenih eksperimentalnih istraživanja sprovedenih na cementnim kompozitima spravljenim sa dodatkom reciklirane gume kao delimičnom zamenom sitnog rečnog agregata. Analizirana su različita svojstva cementnih maltera kako u svežem, tako i u očvrslom stanju. Od svojstava u svežem stanju ispitani su: zapreminska masa, konzistencija i sadržaj uvučenog vazduha. $U$ očvrslom stanju, ispitana su sledeća svojstva: zapreminska masa, mehanička svojstva (čvrstoća pri pritisku i pri savijanju), modul elastičnosti, athezija za betonsku podlogu, upijanje vode, otpornost na mraz i brzina prostiranja ultrazvuka. Dobijeni rezultati pokazali su da se reciklirana guma može uspešno upotrebiti kao delimična zamena za klasičan (rečni) agregat kod kompozita spravljenih na bazi cementa, u skladu sa konceptom održivog razvoja. Istraživanje je pokazalo da od procenta zamene rečnog agregata recikliranom gumom u velikoj meri zavise fizičko-mehanička svojstva cementnih kompozita, a naročito zapreminska masa, čvrstoća, adhezija i otpornost na dejstvo mraza. Najbolji rezultati dobijeni su pri ispitivanju otpornosti na dejstvo mraza.

Ključne reči: Kompozit • Reciklirana guma • Malter • Prirodni rečni agregat • Cement • Fizičko-mehanička svojstva 